\title{
Behaviour and habitat utilisation of seven demersal fish species on the Bay of Biscay continental slope, NE Atlantic
}

\author{
Franz Uiblein $^{1, *}$, Pascal Lorance ${ }^{2}$, Daniel Latrouite ${ }^{2}$ \\ ${ }^{1}$ Institute of Zoology, University of Salzburg, Hellbrunnerstr. 34, 5020 Salzburg, Austria \\ ${ }^{2}$ IFREMER, Technopole Brest-Iroise, BP 70, 29280 Plouzané, France
}

\begin{abstract}
Much is known in very broad terms about the distribution of deep-sea fishes, but information on fine-scale habitat selection and behaviour in the largest living space on earth is still rare. Based on video sequences from 4 dives performed with the manned submersible 'Nautile' at depths between 400 and $2000 \mathrm{~m}$ in the Bay of Biscay, NE Atlantic, we studied the behaviour of co-occurring slope-dwelling deep-sea fishes. Five different habitats were identified according to depth range or topographical and hydrological characteristics. For each fish species or genus that could be identified, estimates of absolute abundance were provided. The most frequently occurring species, roundnose grenadier Coryphaenoides rupestris, blackmouth catshark Galeus melastomus, bluemouth Helicolenus dactylopterus dactylopterus, orange roughy Hoplostethus atlanticus, North Atlantic codling Lepidion eques, greater forkbeard Phycis blennoides, and northern cutthroat eel Synaphobranchus kaupi were quantitatively compared with respect to the relative frequencies of disturbance responses to the submersible, locomotion behaviour, and vertical positioning above the bottom. Clear variations in behaviour and abundance among species and habitats were found, reflecting both species-specific and flexible adjustment to small-scale spatial and temporal variability on the Bay of Biscay continental slope. These results have important implications for the development of sustainable deep-water fisheries management.
\end{abstract}

KEY WORDS: Submersible observations $\cdot$ Assemblage structure $\cdot$ Density $\cdot$ Locomotion $\cdot$ Vertical positioning $\cdot$ Foraging $\cdot$ Species-specific $\cdot$ Behavioural flexibility

Resale or republication not permitted without written consent of the publisher

\section{INTRODUCTION}

The structure of ecological communities is frequently influenced by the prevailing environmental conditions of the respective habitat and organismspecific responses to these conditions. In a remote living space like the deep sea, it was long believed that assemblages of co-occurring species are mainly shaped by depth-related gradients in light, food abundance, or temperature. More recently, evidence increased the supposition that there are considerable affinities between assemblages living in the deep sea and those of surface waters, as many deep-sea dwellers do extend their distribution ranges beyond ecologically delimited areas and adapt to a large set of environmental conditions (e.g. Gage \& Tyler 1991, Uiblein et al. 1996). Moreover, several studies of fish assemblages in slope waters have indicated a rather 'individualistic' behaviour, with co-occurring species differing significantly among themselves in their responses to specific factors such as illumination level, habitat structure, local hydrology, food abundance, or predation risk (e.g. Uiblein et al. 1994, Uiblein 1996, Merrett \& Haedrich 1997).

Species-specific habitat selection and utilisation may play an important role in local aggregation formation and small-scale variation in species composition and diversity in particular slope areas such as seamounts (Koslow 1997, Uiblein et al. 1999, Fock et al. 2002), canyons (Murdoch et al. 1990, Uiblein et al. 1998, 
Lorance et al. 2002), or the mid-water close to oceanic islands (Uiblein \& Bordes 1999, Wienerroither 2001). Comparative studies of food selection based mainly on stomach content analyses indicate considerable differences in foraging behaviour among deep-sea fish species based on a wide array of food-search strategies employed (see Gartner et al. 1997 for review). Grouping of sets of taxa into clearly separable feeding guilds seems to be rather difficult (Gartner et al. 1997).

In order to better understand how co-occurring deep-sea fish species respond to their immediate surroundings, a direct in situ comparative approach with identification of small-scale habitat utilisation patterns and individual behavioural activity in relation to environmental cues is necessary. Observations from submersibles and dropped cameras provided preliminary evidence that deep-sea fishes show a rich repertoire of behavioural activities (e.g. Isaacs \& Schwartzlose 1975, Cohen 1977, Chave \& Mundy 1994). In the last few years, photographs or video recordings from landers or submersibles have been increasingly employed to obtain data on behavioural activity and habitat selection of fishes encountered near experimentally exposed baits or during dives in selected habitats (Mahaut et al. 1990, Priede et al. 1991, Collins et al. 1999, Fricke \& Hissmann 2000, Lorance et al. 2000, Priede \& Bagley 2000). Recent interest has focused on slope areas with spatially and temporally rather varying conditions, such as in the Monterey Bay in the NE Pacific (Yoklavich et al. 2000) or the Bay of Biscay in the NE Atlantic (Mahaut et al. 1990, Latrouite et al. 1999, Lorance et al. 2000).

Recently published data on the behaviour of demersal deep-sea fishes of the Bay of Biscay continental slope (Lorance et al. 2002, Uiblein et al. 2002) have demonstrated that video recordings made during transects with manned submersibles should not only allow a qualitative descriptive analysis of behavioural performance, but also a quantitative statistical comparison of those species which are encountered at high densities and can be easily identified. Preliminary evidence for speciesspecific differences in locomotion and habitat selection was also presented based on dives of the OBSERVHAL 98 cruise with the manned submersible 'Nautile' in the Bay of Biscay (Uiblein et al. 2001), but no statistical comparisons between and within different habitats were made in this exploratory approach.
In this study, we further analyze dives from the OBSERVHAL 98 cruise that were carried out at depths between 400 and $2000 \mathrm{~m}$. Based on an ecological characterisation and census of 5 different habitats and a quantitative comparison of deep-sea fish behaviour, we examine the hypothesis that co-occurring deep-sea fishes show species-specific habitat use and behaviour, with particular interest in the variation among species and habitats in the behavioural responses to the submersible, in the locomotion modes adopted and in the vertical positioning above the bottom.

\section{MATERIALS AND METHODS}

Dives and habitats. Four dives with horizontal transects close to the bottom at depths between 420 and $1850 \mathrm{~m}$ were carried out in the Bay of Biscay between 17 May and 1 June 1998 using the manned submersible 'Nautile' (Fig. 1) (see also Latrouite et al. 1999). During each dive, continuous video recordings by a fixed and a mobile camera positioned in front of the submersible were made. This allowed the monitoring of a visual field of about $5 \mathrm{~m}$ in width and over distances of 10 to $15 \mathrm{~m}$ in front of the submersible. The submersible moved ca. $1.5 \mathrm{~m}$ above the bottom, interrupted by short stops, at about 0.5 to 0.7 knots. For

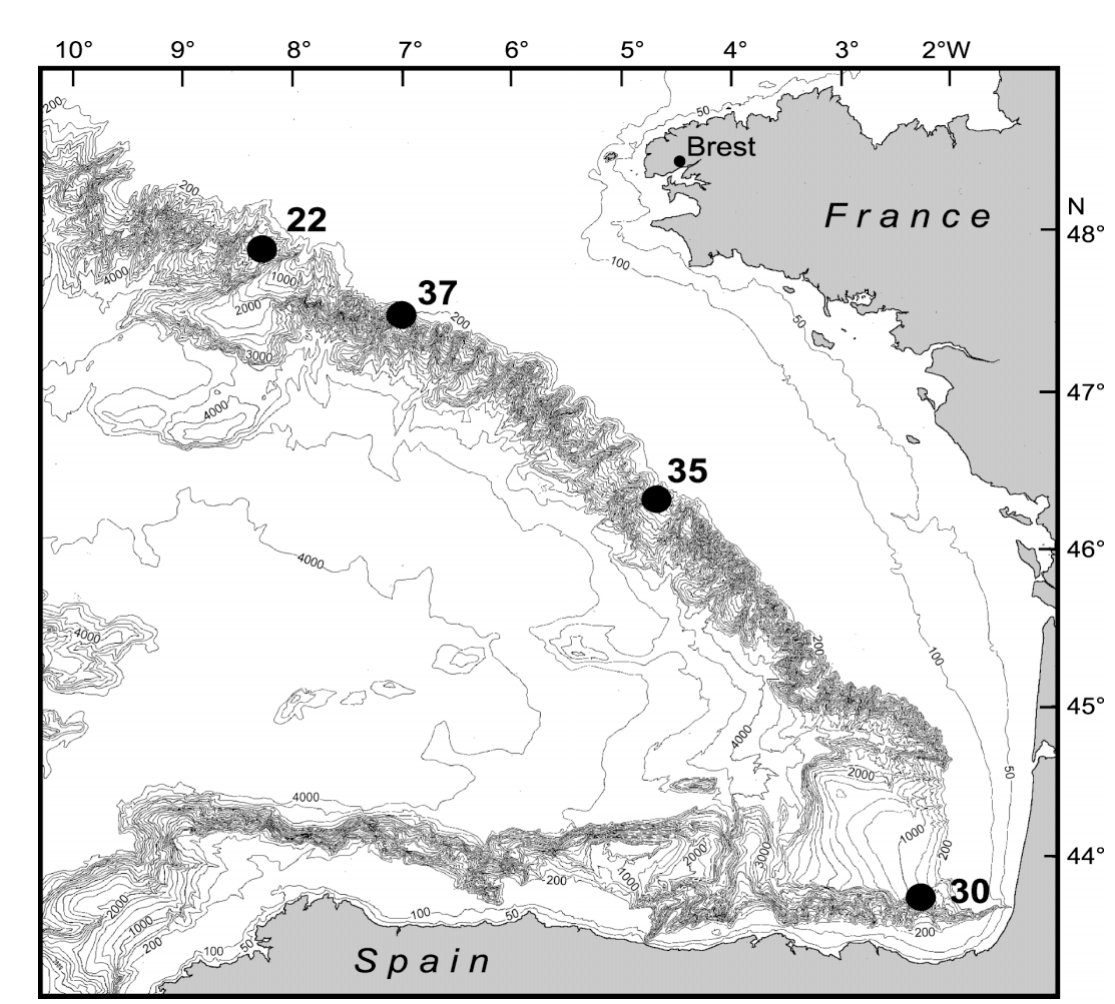

Fig. 1. Map of the study area showing positions of dives and topographical details 
each study area, navigation and temperature data processed with ADELIE software (Lecornu 2000) were obtained. Topographic maps and climatological data were available, too. As no measures of water movement were made during the dives, estimates of current velocity and temporal characteristics were obtained from the video recordings that included spoken comments of the pilot and the participating scientist.

Five different habitats (S1, S2, S3a, S3b, S4) were distinguished according to bathymetric position of the respective dive along the slope (upper slope, upper mid slope, lower mid slope, lower slope) and specific topographical and hydrological features (Table 1). This separation scheme follows 2 autecological studies of orange roughy Hoplostethus atlanticus and northern cutthroat eel Synaphobranchus kaupi, in which behavioural data of the 3 deeper dives (Dives 22, 30 and 35,
Table 1) were analysed (Lorance et al. 2002, Uiblein et al. 2002). Accordingly, a distinct area of Dive 35situated in a small canyon, completely devoid of currents and with a dense aggregation of $H$. atlanticuswas treated as a separate habitat, thus resulting in 2 habitats referred to as S3a and b (Table 1). During the transect of Dive 37, rather uniform conditions (similar to Dives 22 and 30) were encountered and, hence, only a single habitat was identified.

For each habitat the following details were provided: observational data (distance, time, and duration of crossing of the respective transect part); local conditions (depth range and bottom type), including temporal conditions influenced by tidal effects and internal waves (current velocity, current temporal characteristics and temperature); and the results of the fish visual census (Table 1).

Table 1. Characteristics of the 5 habitats identified during the 4 submersible dives, number of fish encountered, and the estimated density per ha for each of the identified fish species/genera

\begin{tabular}{|c|c|c|c|c|c|}
\hline \multirow{4}{*}{$\begin{array}{l}\text { Initial position: } \\
\text { Final position: } \\
\text { Habitat: }\end{array}$} & \multirow{4}{*}{$\begin{array}{c}\text { Dive } 37 \\
\text { 1 June } 1998 \\
47^{\circ} 29^{\prime} \mathrm{N}, 06^{\circ} 42.33^{\prime} \mathrm{W} \\
47^{\circ} 28^{\prime} \mathrm{N}, 06^{\circ} 39.42^{\prime} \mathrm{W} \\
\mathrm{S} 1\end{array}$} & \multirow{4}{*}{$\begin{array}{l}\text { Dive } 22 \\
17 \text { May } 1998 \\
47^{\circ} 53.90^{\prime} \mathrm{N}, 08^{\circ} 12.50^{\prime} \mathrm{W} \\
47^{\circ} 54.71^{\prime} \mathrm{N}, 08^{\circ} 10.79^{\prime} \mathrm{W} \\
\mathrm{S} 2\end{array}$} & \multicolumn{2}{|c|}{$\begin{array}{c}\text { Dive } 35 \\
\text { 30 May } 1998\end{array}$} & \multirow{4}{*}{$\begin{array}{c}\text { Dive } 30 \\
26 \text { May } 1998 \\
43^{\circ} 39.98^{\prime} \mathrm{N}, 02^{\circ} 20.02^{\prime} \mathrm{W} \\
43^{\circ} 42.28^{\prime} \mathrm{N}, 02^{\circ} 18.92^{\prime} \mathrm{W} \\
\mathrm{S} 4\end{array}$} \\
\hline & & & \multirow{2}{*}{\multicolumn{2}{|c|}{$\begin{array}{l}46^{\circ} 15.15^{\prime} \mathrm{N}, 04^{\circ} 33.83^{\prime} \mathrm{W} \\
46^{\circ} 12.62^{\prime} \mathrm{N}^{\prime} 04^{\circ} 34.12^{\prime} \mathrm{W}\end{array}$}} & \\
\hline & & & & & \\
\hline & & & S3a & S3b & \\
\hline Distance crossed (m) & 5300 & 2900 & 5100 & 430 & 1900 \\
\hline Time (h) & $10: 15-14: 12$ & $11: 49-15: 41$ & $09: 44-14: 20$ & $12: 07-12: 35$ & $10: 20-11: 53$ \\
\hline Duration (min) & 237 & $168^{\mathrm{a}}$ & 274 & 28 & 93 \\
\hline Initial-final depth (m) & $538-422$ & 1099-933 & $1560-1155$ & $1442-1393$ & $1848-1822$ \\
\hline Bottom type & $\begin{array}{l}\text { Soft mixed with } \\
\text { hard, structured }\end{array}$ & $\begin{array}{l}\text { Soft with high } \\
\text { bioturbation }\end{array}$ & $\begin{array}{l}\text { Hard, highly } \\
\text { structured }\end{array}$ & $\begin{array}{l}\text { Hard, highly } \\
\text { structured }\end{array}$ & $\begin{array}{l}\text { Soft with } \\
\text { bioturbation }\end{array}$ \\
\hline Current velocity $\left(\mathrm{m} \mathrm{s}^{-1}\right)$ & $0.1-0.5$ & $0.1-0.5$ & $0.1-1$ & $0-0.1$ & $<0.1$ \\
\hline $\begin{array}{l}\text { Current temporal } \\
\text { characteristics }\end{array}$ & Constant & Highly variable & Variable & Constant & Constant \\
\hline Temperature $\left({ }^{\circ} \mathrm{C}\right)$ & $10.9-11.6$ & $8.26-9.58$ & $4.63-9.11$ & $5.06-5.59$ & $5.01-5.16$ \\
\hline Aphanopus carbo & - & - & $1(0.4)$ & - & - \\
\hline Bathypterois sp. & - & $1(0.7)$ & - & - & $2(2.1)$ \\
\hline Beryx decadactylus & $10(3.8)$ & - & - & _- & - \\
\hline $\begin{array}{l}\text { Coryphaenoides } \\
\text { rupestris }\end{array}$ & - & $73(50.3)$ & $82(32.2)$ & $37(172.1)$ & $26(27.4)$ \\
\hline Galeus melastomus & $30(11.3)$ & - & - & - & - \\
\hline $\begin{array}{l}\text { Helicolenus dactylopterus } \\
\text { dactylopterus }\end{array}$ & $57(21.5)$ & - & - & - & - \\
\hline Hoplostethus atlanticus & - & $1(0.7)$ & $24(9.4)$ & 351 (1632.6) & $1(1.1)$ \\
\hline Lepidion eques & - & $48(33.1)$ & $4(1.6)$ & - & - \\
\hline Merluccius merluccius & $1(0.4)$ & - & - & - & - \\
\hline Molva molva & $19(7.2)$ & - & - & - & - \\
\hline Mora moro & - & $19(13.1)$ & $1(0.4)$ & - & - \\
\hline Neocyttus helgae & - & - & $15(5.9)$ & $4(18.6)$ & - \\
\hline Notacanthus sp. & - & $1(0.7)$ & $9(3.5)$ & $2(9.3)$ & $10(10.5)$ \\
\hline Phycis blennoides & $46(17.4)$ & - & - & - & - \\
\hline Synaphobranchus kaupi & - & $37(25.5)$ & $29(11.4)$ & _- & $72(75.8)$ \\
\hline Trachyscorpia cristulata & - & $6(4.1)$ & $1(0.4)$ & - & - \\
\hline Other fishes & $56(21)$ & $43(29.7)$ & $94(36.8)$ & $16(74.4)$ & $91(95.7)$ \\
\hline Total fish & $219(82.6)$ & $229(157.9)$ & $260(102)$ & $410(1907)$ & $202(212.6)$ \\
\hline
\end{tabular}


Visual census. In the present study, mainly the videotapes produced with the fixed camera were analysed. The analysis started immediately after an individual fish appeared on the video screen. Identification of species or higher taxa was based on the size and form of the body, head and fins, and colour patterns. The spoken comments and the recordings of the mobile camera also provided help with identification. Apart from assessing the relative abundance of each species (in \% total fish individuals encountered), absolute density estimates were calculated for each habitat based on the transect length and the mean width of the visual field provided by the video camera.

Quantitative behavioural analysis. In the behavioural analysis only the recordings of species with more than 20 individuals per habitat were used. Fishes visualised on video with high or increasing swimming speed indicating burst swimming in response to prior disturbance by the submersible ('disturbance upon arrival') were excluded from the analysis of locomotion behaviour and vertical body position. Four locomotion activity categories were identified: inactive without any movement, station holding (body stationary with active swimming), drifting (movement in lateral or backward direction with or without swimming activity), and forward movement (clear active forward swimming movements). Furthermore, 3 categories for vertical body position in relation to bottom surface were determined: attached to bottom (the body touching the bottom surface), slightly above the bottom (at distances of less than 1 body length) and well above bottom (distance from bottom exceeds 1 body length).

During the behavioural recordings, the submersible frequently got closer to the fishes, with increasing illumination intensity caused by the front lights. If a disturbance response was observed during this process (i.e. a marked change in activity level and/or locomotion behaviour), the recordings of locomotion or body position data were stopped immediately before the occurrence of this behavioural change. The disturbance behaviour during submersible approach was analysed as a separate category together with the pre-arrival disturbance (see above).

For statistical comparisons of these categorical data among species and habitats, G-tests of independency were carried out (Sokal \& Rohlf 1981).

\section{RESULTS}

\section{Habitat characterisation}

The 5 habitats differed from each other in depth-range covered, bottom type, current ve-

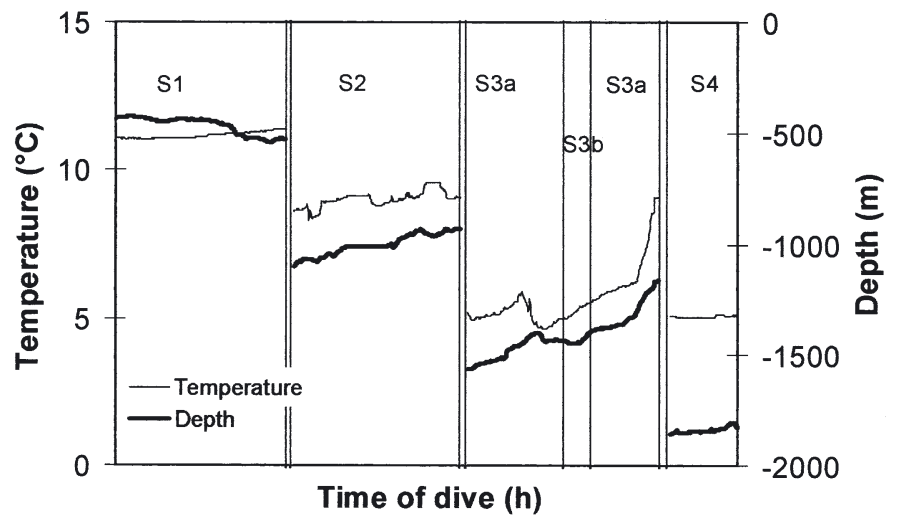

Fig. 2. Temperature and depth along the dive transects studied (for time of dive see Table 1)

locity, current temporal characteristics, and temperature (Table 1, Figs. $2 \& 3$ ). In S2 and S4 the bottom was covered with fine sediment with the only marked structuring deriving from bioturbation. In S2, elevated deposits of fine sediment with the formation of hilly structures were observed. This habitat was also highly turbid with many small particles drifting in the water. The habitats S1 and S3a,b showed a highly structured hard or mixed bottom.

In S3a, at least in some parts, a particularly high current velocity was encountered. In S4 water movement was very slow. Little or no current was recorded in S3b. Current temporal characteristics differed mainly between rather instantaneously changing, variable currents in S2 and S3a and constant conditions encountered in the other 3 habitats (Table 1). This becomes particularly evident when the depth and temperature curves along the dive transects (Fig. 2) and the deviations from the mean temperature in the

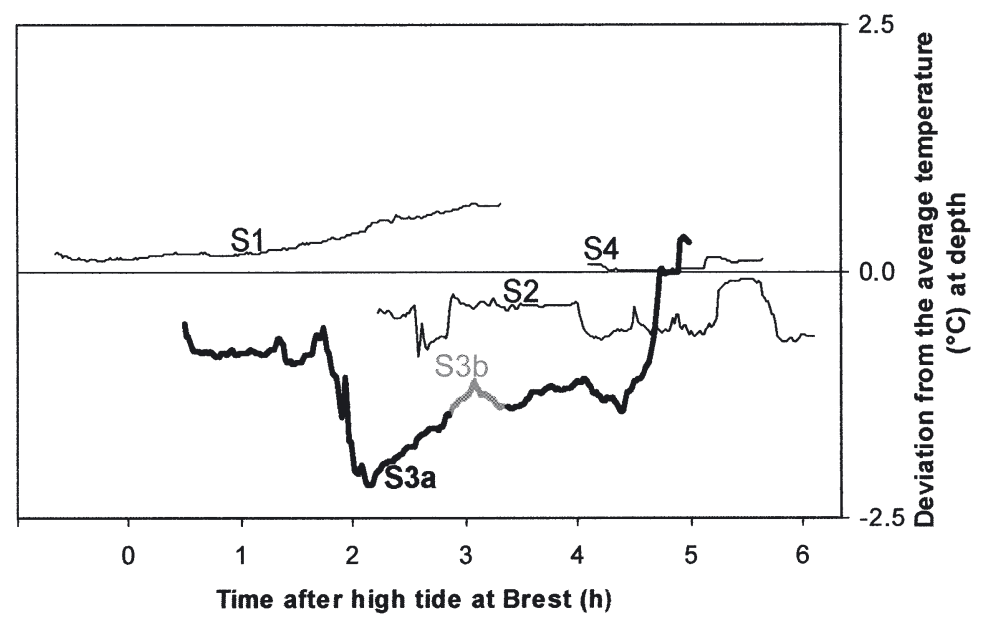

Fig. 3. Temperature variations, estimated as the deviations of the observed temperature from the average monthly temperature at the same depth during the 5 dive transects analysed. Corresponding habitats indicated 
respective area of each dive (Fig. 3) are compared. The high current variability in S3a is also reflected by a wide temperature range that overlapped in some parts with shallower (S2) or deeper (S4) habitats. Several instantaneous fluctuations in temperature were recorded in S2, whereas the shallowest (S1) and the deepest (S4) dive showed rather constant hydrological conditions (Fig. 3).

\section{Habitat-species associations}

A total of 1320 individual fish were encountered in the 5 habitats of which 1020 could be identified to species or genus level, resulting in 16 taxa belonging to 14 families (Table 1). The 7 most abundant species selected for the quantitative behavioural comparison were roundnose grenadier Coryphaenoides rupestris, blackmouth catshark Galeus melastomus, bluemouth Helicolenus dactylopterus dactylopterus, orange roughy Hoplostethus atlanticus, North Atlantic codling Lepidion eques, greater forkbeard Phycis blennoides, and northern cutthroat eel Synaphobranchus kaupi.

Helicolenus dactylopterus dactylopterus was the most abundant species in the shallowest habitat ( $\mathrm{S} 1$, Table 1). Coryphaenoides rupestris dominated in 2 habitats (S2, S3a) and Hoplostethus atlanticus and Synaphobranchus kaupi in 1 habitat each (S3b and S4, respectively). The total fish density varied among habitats, but did not follow any depth gradient. The density in the shallowest habitat (S1) was rather low, whereas in the deepest habitat (S4) a comparatively high density was encountered. The high fish abundance in S3b mainly reflected the $H$. atlanticus aggregation (see also Lorance et al. 2002). However, C. rupestris also occurred there at a rather high density.

\section{Behavioural comparison among species}

Of the 7 most abundant species, a total of 618 individuals were behaviourally analysed. Of the orange roughy aggregation $(\mathrm{n}=351$, Table 1$)$ only a subsample of 57 individuals was considered. The 28 individuals that appeared to be already disturbed upon arrival (Fig. 4) were excluded from the further behavioural analysis. The results of pairwise statistical comparisons of disturbance response, locomotion activity, and position in the water column for each of the 5 habitats are shown in Table 2.

In S1, the disturbance response of Phycis blennoides was significantly higher compared to Helicolenus dactylopterus dactylopterus (Fig. 4, Table 2). With respect to locomotion behaviour examined in this habitat, all species differed significantly from each other with $H$. d. dactylopterus remaining completely inactive, $P$. blennoides performing a relatively high rate of station holding, and Galeus melastomus exhibiting more forward locomotion. Furthermore, all species differed significantly from each other in the water column position with $H$. d. dactylopterus occurring almost exclusively attached to the bottom, P. blennoides

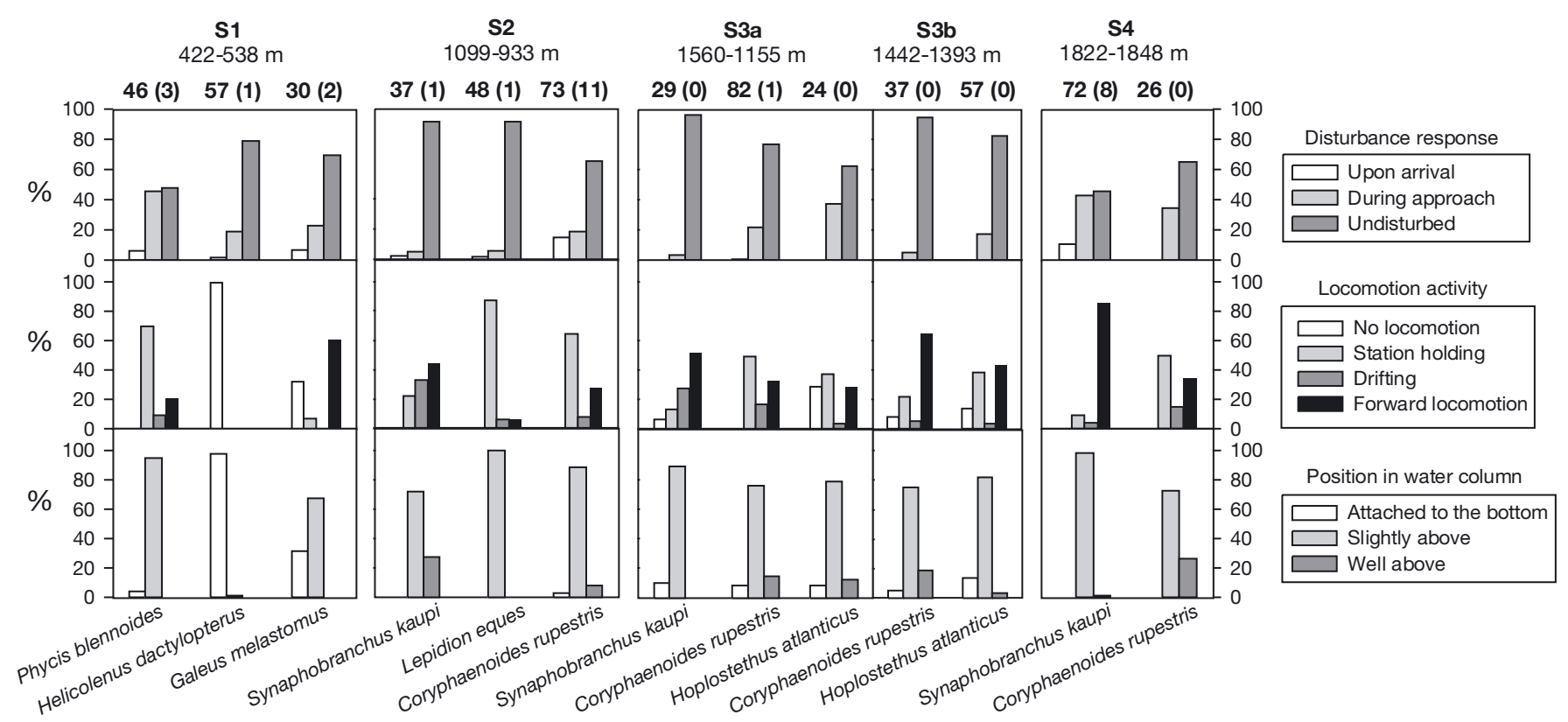

Fig. 4. Percentage of the behavioural category shown by the respective species in each of the 5 habitats. For each habitat the depth ranges are indicated. Total number of individuals per species and habitat, with the number of individuals showing disturbance response upon arrival in parentheses, is given in bold 
mainly slightly above and G. melastomus intermediate between the other 2 .

In S2, the disturbance response of Coryphaenoides rupestris was significantly higher compared to Synaphobranchus kaupi and Lepidion eques (Fig. 4, Table 2). All 3 species differed significantly from each other in locomotion behaviour, with $S$. kaupi showing more drifting and the other 2 species more station holding. In $L$. eques less forward locomotion was observed than in C. rupestris and $S$. kaupi. All 3 species differed significantly from each other in the water column position, with $S$. kaupi encountered more often well above the bottom, L. eques found exclusively slightly above the bottom and C. rupestris intermediate between the 2 other species.

In S3a, Hoplostethus atlanticus showed a significantly higher disturbance response than Synaphobranchus kaupi (Fig. 4, Table 2). These 2 species and Coryphaenoides rupestris differed significantly from each other in locomotion activity, with $H$. atlanticus being frequently inactive without locomotion, $C$. rupestris performing a high rate of station holding, and $S$. kaupi displaying mainly forward locomotion and clearly less station holding than the other 2 species. $C$. rupestris was encountered at a significantly higher position in the water column than $S$. kaupi.

In S3b, no significant differences in disturbance response and locomotion activity were found. Coryphaenoides rupestris adopted a significantly more elevated water column position compared to Hoplostethus atlanticus (Fig. 4, Table 2).

In $\mathrm{S} 4$, the disturbance response to the submersible (including both pre-arrival and approach disturbance) was significantly higher in Synaphobranchus kaupi than in Coryphaenoides rupestris (Fig. 4, Table 2). In this habitat, $S$. kaupi performed significantly more active forward movement than $C$. rupestris, while the latter adopted a much higher rate of station holding. Furthermore, $S$. kaupi remained mainly slightly above the bottom, whereas $C$. rupestris was encountered well above the bottom significantly more often.

\section{Behavioural comparison among habitats}

In Coryphaenoides rupestris the disturbance response upon arrival was significantly higher in S2 compared to S3a,b and S4 (Fig. 4, Table 2). Moreover, this species demonstrated a higher disturbance during approach in S4 compared to S3b. In S3b, the population differed significantly in locomotion behaviour from those of the other 3 habitats in showing more active forward movement and less station holding. With respect to water column position, no significant differences among habitats were found.

Hoplostethus atlanticus showed no significant differences between the 2 habitats, S3a and $b$, in the 3 behavioural parameters (Fig. 4, Table 2).

In Synaphobranchus kaupi the disturbance response was significantly higher in S4 compared to S2 and S3a (Fig. 4, Table 2). In this deepest habitat this species moved forward at a significantly higher rate and with less drifting than in the 2 other habitats. Moreover, this species adopted a significantly more elevated position in the water column in S2 compared to S3a and S4.

\section{DISCUSSION}

Our in situ study based on the analysis of video sequences recorded during manned submersible transects in the 
Table 3. Frequency indices for behavioural categories. +++: very high; ++: high; +: low; -: very low or 0

\begin{tabular}{|c|c|c|c|c|c|c|c|c|c|c|}
\hline Species & 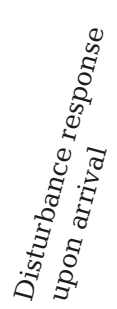 & 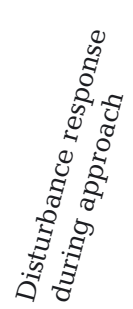 & 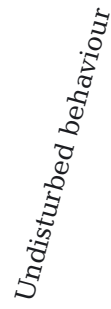 & 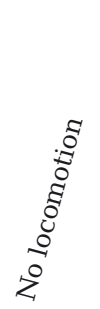 & 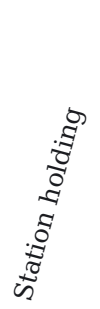 & 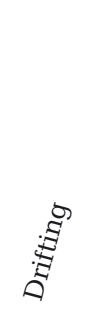 & 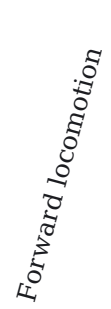 & 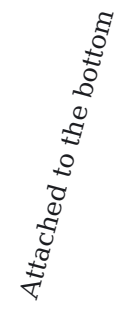 & 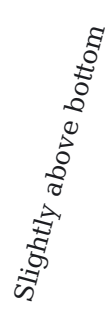 & 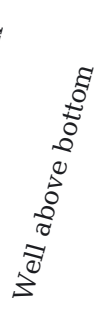 \\
\hline Phycis blennoides & - & ++ & ++ & - & +++ & - & - & - & +++ & - \\
\hline Helicolenus d. dactylopterus & - & + & +++ & +++ & - & - & - & +++ & - & - \\
\hline Galeus melastomus & - & + & +++ & + & - & - & +++ & ++ & ++ & - \\
\hline Synaphobranchus kaupi & + & + & +++ & - & + & ++ & +++ & - & +++ & + \\
\hline Lepidion eques & - & - & +++ & - & +++ & - & - & - & +++ & - \\
\hline Coryphaenoides rupestris & + & + & +++ & - & ++ & + & ++ & - & +++ & + \\
\hline Hoplostethus atlanticus & - & + & +++ & + & ++ & - & ++ & + & +++ & - \\
\hline
\end{tabular}

Bay of Biscay represents one of the very first steps in studying the behavioural ecology of deep-sea fishes. It demonstrates that environmental conditions and fish assemblages in slope waters are interrelated in a rather complex way. Considerable differences among habitats were found in ecological factors, faunal composition and fish abundance. The interspecific and habitat-related variations in disturbance response, locomotion activity, or water column position encountered provide new information (see Table 3 for a summary of the findings). Our approach should provide a very valuable tool for a much more detailed ecological characterisation of each deep-sea species than was previously possible (e.g. Whitehead et al. 1986).

Coryphaenoides rupestris can be distinguished from the other co-occurring species by high activity level, increased forward locomotion, a higher body position and-dependent upon the respective habitat conditions-a relatively high disturbance response and frequent station holding. This benthopelagic species feeds mainly on zooplankton, but also on small midwater fishes (Geistdoerfer 1979, Mauchline \& Gordon 1984a, Atkinson 1995). In general, the food of this species is rather small-sized compared to most other species analysed here. According to earlier observations, C. rupestris makes active excursions into the open water, most probably to feed (Haedrich 1974, Zaferman 1992, Atkinson 1995). But it may also forage to some extent near the bottom on epifauna (Du Buit 1978). Vertical migrations may be synchronised with the tidal cycle, as preliminary acoustic and submersible observations suggest (Zaferman et al. 1991). Interestingly, C. rupestris switched from a more station-holding behaviour (similar to Phycis blennoides and Lepidion eques) to a widely foraging mode with active forward locomotion (similar to
Synaphobranchus kaupi) between 2 adjacent habitats of the same dive, indicating highly flexible adjustment to different hydrological conditions. In contrast to the purely predatory Hoplostethus atlanticus, $C$. rupestris most probably also feeds on dead zooplankton that may be trapped at deep-sea bottoms devoid of currents. This would explain the high activity level of this species in the habitat of the $H$. atlanticus aggregation. The frequent disturbance response of C. rupestris in the deepest habitat may reflect an increased attention to environmental cues probably related to the need to increase the search volume with lower food density.

Galeus melastomus showed phases of inactivity similar to Hoplostethus atlanticus. However, this species rested directly on the bottom and occurred in a shallower habitat with a moderate current. Also - in contrast to $H$. atlanticus-active G. melastomus showed a high rate of forward locomotion close to the bottom, which indicates a bottom-associated wide-ranging foraging behaviour. This species feeds mainly on benthopelagic mobile prey such as fishes, cephalopods and decapods, but to some extent also on benthic organisms (Saldanha et al. 1995, Santos \& Borges 2001, Velasco et al. 2001). The rather high inactivity level in this species is in clear contrast to most other sharks and chondrichthyans observed during the OBSERVHAL dives (Lorance et al. 2000).

Helicolenus dactyloperus dactylopterus was encountered attached to the bottom and inactive, without showing any locomotion or response to the submersible. This species may therefore be characterized as a typical sit-and-wait predator that may attack its prey-mainly benthic crustaceans, fishes, and gelatinous plankton (Mianzan et al. 1996, Gaertner et al. 1999, Nouar \& Maurin 2000) — at rather short distances 
and close to the bottom. This assumption is further substantiated by the low disturbance response to the submersible, which may reflect a highly cryptic foraging and antipredator strategy typical of sit-and-wait predators.

In an earlier autecological study of Hoplostethus atlanticus observed with the 'Nautile' during a total of 13 dives in the Bay of Biscay, the obviously 2-fold resource utilisation strategy adopted by this species was discussed in detail (Lorance et al. 2002). H. atlanticus formed a dense aggregation of inactive or station holding individuals in the canyon habitat (S3b) and showed a relatively low disturbance level that contrasts with previously observed intensive avoidance responses of this species to larger approaching objects in the open water (Koslow et al. 1995). This pelagic and benthopelagic forager (Rosecchi et al. 1988, Bulman \& Koslow 1992) seems to adopt reduced activity phases during stays close to the bottom in areas devoid of currents that may allow energetic recovery between foraging trips into the open water (cf. Lorance et al. 2002). Adjacent to the canyon habitat (S3b) in S3a the current was rather strong, and the particularly fluctuating temperatures found there indicate high hydrological activity. Such conditions may be optimal for the accumulation of planktonic prey. Nevertheless, also in this much more turbulent habitat, several $H$. atlanticus showed a rather high inactivity level, resting in calmer microhabitats. A comparison of colour patterns in the 2 habitats (Lorance et al. 2002), however, suggests that some of the more active specimens may have avoided the submersible before encounter in S3b, and hence were not registered.

Lepidion eques and the shallower occurring Phycis blennoides can be characterised as active station holders. They feed mainly on epibenthic or benthopelagic crustaceans (Du Buit 1978, Mauchline \& Gordon 1984b). Station holding is an effective foraging strategy in currents that has been investigated in more detail in coastal marine as well as river-dwelling fishes (e.g. Webb 1989, Guensch et al. 2001). In deeper waters, station holding may be the typical locomotion behaviour of benthic gadiform fishes. Apart from $L$. eques and $P$. blennoides, the less abundant ling Molva molva and Mora moro also frequently showed this behaviour (authors' pers. obs.). P. blennoides clearly differed in locomotion and disturbance behaviour from the co-occurring Helicolenus dactylopterus dactyloperus and Galeus melastomus and was the behaviourally most active in the shallowest habitat (S1). These data point to a high vigilance level in $P$. blennoides that may allow an increase in the search volume and an awareness of environmental changes such as the sudden occurrence of prey or predators at rather large distances.
The high activity level and frequent forward locomotion shown by Synaphobranchus kaupi indicate a wide-ranging foraging mode adopted by this typical scavenger that-in concert with a well adapted olfactory system-may allow detection and approach of food particles over larger distances (Uiblein et al. 2002). A similar behaviour has been found in blind cave salamanders that search for low-density living or dead prey (Uiblein et al. 1992). The presence of currents may improve the search efficiency by increasing the allochthonous nutrient input and enhancing the encounter with odour plumes from food sources. Consequently, areas with very weak or no currents may be less selected or even avoided by $S$. kaupi, which is confirmed by the absence of this species in the Hoplostethus atlanticus aggregation habitat (S3b). In the deepest habitat (S4), that provided slow and constant currents, the density of this species was highest. With strong currents and distance to the bottom increased, this eel may be morphologically less adapted to firmly hold station close to the bottom, in contrast to the other teleosts studied. The variation in disturbance responses among habitats possibly indicates local differences in sensitivity due to intrinsic factors such as a depth-related increase in body size (Merrett \& Domanski 1985, Gordon \& Mauchline 1996) and sensory surface or an enhanced attention level that allows matching with lower food density in the deepest habitat (Uiblein et al. 2002). The latter interpretation may also have relevance for understanding the increased disturbance responses of Coryphaenoides rupestris. The higher forward locomotion rate of $S$. kaupi in the deepest habitat may serve to further increase the search volume (Uiblein et al. 2002).

In conclusion, demersal fishes of the Bay of Biscay continental slope show both species-specific and flexible adjustment to small-scale spatial and temporal ecological variability. These findings have important implications for deep-water fisheries, as the diversity of behaviours observed should also affect the catching efficiency of fishing gears with respect to species and habitat type. Such influences should be considered in the development of sustainable management strategies, as deep-sea fishes are highly sensitive to overexploitation (e.g. Merrett \& Haedrich 1998, Haedrich et al. 2001).

Acknowledgements. The present study was financially supported by the scientific department of the French Embassy in Vienna, the Austrian Academic Exchange Service (ÖAD), and a bilateral Amadeus project between France and Austria, project no. V13. We thank 3 anonymous referees for their comments. 


\section{LITERATURE CITED}

Atkinson DB (1995) The biology and fishery of roundnose grenadier (Coryphaenoides rupestris Gunnerus 1765) in the North West Atlantic. In: Hopper AG (ed) Deep-water fisheries of the Northern Atlantic Slope. Kluwer Academic Publishers, Dordrecht, p 51-111

Bulman CM, Koslow JA (1992) Diet and food consumption of a deep-sea fish, orange roughy Hoplostethus atlanticus (Pisces: Trachichthyidae), off southeastern Australia. Mar Ecol Prog Ser 82:115-129

Chave EH, Mundy BC (1994) Deep-sea benthic fish of the hawaiian Archipelago, Cross Seamount, and Johnston Atoll. Pac Sci 48:367-409

Cohen DM (1977) Swimming performance of the gadoid fish Antimora rostrata at 2400 meters. Deep-Sea Res 24: 275-277

Collins MA, Priede IG, Bagley PM (1999) In situ comparison of activity of two deep-sea scavenging fishes occupying different depth zones. Proc Roy Soc Lond B 266:2011-2016

$\mathrm{Du}$ Buit MH (1978) Alimentation de quelques poissons téléostéens de profundeur dans la zone du seuil de Wyville Thomson. Oceanol Acta 1:129-134

Fock H, Uiblein F, Köster F, v Westernhagen H (2002) Biodiversity and species-environment relationships of the demersal fish assemblage at the Great Meteor Seamount (subtropical NE Atlantic) sampled by different trawls. Mar Biol 141:185-199

Fricke H, Hissmann K (2000) Feeding ecology and evolutionary survival of the living coelacanth Latimeria chalumnae. Mar Biol 136:379-386

Gartner JV, Crabtree RE, Sulak KJ (1997) Feeding at depth. In: Randall DJ, Farrell AP (eds) Deep-sea fishes. Academic Press, San Diego, p 115-193

Gaertner JC, Mazouni N, Sabatier R, Millet, B (1999) Spatial structure and habitat associations of demersal assemblages in the Gulf of Lions: a multicompartmental approach. Mar Biol 135:199-208

Gage JD, Tyler PA (1991) Deep-sea biology: a natural history of organisms at the deep-sea floor. Cambridge University Press, Cambridge

Geistdoerfer P (1979) Alimentation du grenadier, Coryphaenoides rupestris, dans l'Atlantique nord-est. Cons Int Explor Mer CM G31:10

Gordon JDM, Mauchline J (1996) The distribution and diet of the dominant, slope-dwelling eel, Synaphobranchus kaupi, of the Rockall Trough. J Mar Biol Assoc UK 76: 493-503

Guensch GR, Hardy TB, Addley RC (2001) Examining feeding strategies and position choice of drift-feeding salmonids using an individual-based mechanistic foraging model. Can J Fish Aquat Sci 58:446-457

Haedrich RL (1974) Pelagic capture of the epibenthic rattail Coryphaenoides rupestris. Deep-Sea Res 21:977-979

Haedrich RL, Merrett NR, O'Dea NR (2001) Can ecological knowledge catch up with deep-water fishing? A North Atlantic perspective. Fish Res 51:113-122

Isaacs JD, Schwartzlose RA (1975) Active animals of the deep-sea floor. Sci Am 233:85-91

Koslow JA (1997) Seamounts and the ecology of deep-sea fisheries. Am Sci 85:168-176

Koslow JA, Kloser R, Stanley CA (1995) Avoidance of a camera system by a deepwater fish, the orange roughy (Hoplostethus atlanticus). Deep-Sea Res I 42:233-244

Latrouite D, Désaunay Y, De Pontual H, Troadec H and 8 others (1999) Compte-rendu de mission à la mer OBSERVHAL98 - Observations à finalité halieutique.
Research report RST 99-01, IFREMER, Brest

Lecornu F (2000) ADELIE: Underwater vehicle data postprocessing tools. User guide - v. 1.4. Technical engineering report IFREMER/DNIS/ESI/DLE/DTI/2000-106:1-172

Lorance P, Latrouite D, Seret B (2000) Submersible observations of elasmobranch species in the Bay of Biscay. In: Séret B, Sire JY (eds) 3rd European Elasmobranch Association Meeting, Bologne sur Mer. Societé France Ichthyologie et IRD, Paris, p 29-45

Lorance P, Uiblein F, Latrouite D (2002) Habitat, behaviour and colour patterns of orange roughy Hoplostethus atlanticus (Pisces: Trachichthyidae) in the Bay of Biscay. J Mar Biol Assoc UK 82:321-331

Mahaut ML, Geistdoerfer P, Sibuet M (1990) Trophic stratgegies in carnivorous fishes: their significance in energy transfer in the deep-sea benthic ecosystem (Meriadzek Terrace-Bay of Biscay). Prog Oceanogr 24:223-237

Mauchline J, Gordon JDM (1984a) Diets and bathymetric distributions of the macrourid fish of the Rockall Trough, northeastern Atlantic Ocean. Mar Biol 81:107-121

Mauchline J, Gordon JDM (1984b) Feeding and bathymetric distribution of the gadoid and morid fish of the Rockall Trough. J Mar Biol Assoc UK 64:657-665

Merrett NR, Domanski PA (1985) Observations on the ecology of deep-sea bottom fishes collected off Northwestern Africa: II. The Moroccan slope $\left(27^{\circ}-34^{\circ} \mathrm{N}\right)$, with special reference to Synaphobranchus kaupi. Biol Oceanogr 3: 349-399

Merrett NR, Haedrich R (1997) Deep-sea demersal fish and fisheries. Chapman \& Hall, London

Mianzan HW, Mari N, Prenski B, Sanchez F (1996) Fish predation on neritic ctenophores from the Argentine continental shelf: a neglected food source? Fish Res 27:69-79

Murdoch R, Guo R, McCrone A (1990) Distribution of hoki (Macruronus novaezelandiae) eggs and larvae in relation to hydrography in eastern Cook Strait, September 1987. NZ J Mar Freshw Res 24:529-539

Nouar A, Maurin C (2000) Feeding habits of Helicolenus dactylopterus dactylopterus (Pisces: Scorpaenidae) of the algerian coast. Cah Biol Mar 41:313-320

Priede IG, Bagley PM (2000) In situ studies on deep-sea demersal fishes using autonomous unmanned lander platforms. Oceanogr Mar Biol Annu Rev 38:357-392

Priede IG, Bagley PM, Armstrong JD, Smith KL, Merrett NR (1991) Direct measurement of active dispersal of food-falls by deep-sea demersal fishes. Nature 351:647-649

Rosecchi E, Tracey DM, Weber WR (1988) Diet of orange roughy, Hoplostethus atlanticus (Pisces: Trachichthyidae) on the Challenger Plateau, New Zealand. Mar Biol 99: 293-306

Saldanha L, Almeida AJ, Andrade F, Guerriero J (1995) Observations on the diet of some slope dwelling fishes of southern Portugal. Int Rev Gesamten Hydrobiol 80:217-234

Santos J, Borges T (2001) Trophic relationships in deep-water fish communities off Algarve, Portugal. Fish Res 51: 337-341

Sokal RR, Rohlf FJ (1981) Biometry. WH Freeman, New York

Uiblein F (1996) Constraints and exploratory windows in light-reduced marine habitats. In: Uiblein F, Ott J, Stachowitsch $M$ (eds) Deep-sea and extreme shallow-water habitats: affinities and adaptations. Biosystematics and Ecology Series 11:165-182

Uiblein F, Bordes F (1999) Complex trophic interactions around ocean islands. Ocean Challenge 9(2):15-16

Uiblein F, Durand JP, Juberthie C, Parzefall J (1992) Predation in caves: the effects of differential prey mobility and darkness on the foraging behaviour of two salamanders, 
Euproctus asper and Proteus anguinus. Behav Process 28: 33-40

Uiblein F, Nielsen JG, Klausewitz W (1994) Depth dependent morphological variation in two ophidiiform fishes from the deep Red Sea: evidence for species-specific structure in vertical distribution. Cybium 18:15-23

Uiblein F, Ott J, Stachowitsch M (eds) (1996) Deep-sea and extreme shallow-water habitats: affinities and adaptations. Biosystematics and Ecology Series, Austrian Academy of Sciences, Vienna

Uiblein F, Bordes F, Castillo R, Ramos A (1998) Spatial distribution of shelf- and slope-dwelling fishes collected by bottom longline off Lanzarote and Fuerteventura, Canary Islands. PSZN I: Mar Ecol 19:53-66

Uiblein F, Geldmacher A, Köster F, Nellen W, Kraus G (1999) Species composition and depth distribution of fish species collected in the area of the Great Meteor Seamount, Central Eastern Atlantic, during cruise M42/3, with seventeen new records. Informes Técnicos del Instituto Canario de Ciencias Marinas 5:47-85

Uiblein F, Lorance P, Latrouite D (2001) Interspecific comparison of deep-sea locomotion behaviour and habitat selection. Northwest Atlantic Fisheries Organization Scientific Reports. Doc. N4522, 01/127:5

Uiblein F, Lorance P, Latrouite D (2002) Variation in locomotion behaviour in northern cutthroat eel (Synapho-

Editorial responsibility: Otto Kinne (Editor),

Oldendorf/Luhe, Germany branchus kaupi) on the Bay of Biscay continental slope. Deep-Sea Res I 49:1689-1703

Velasco F, Olaso I, Sanchez F (2001) The role of cephalopods as forage for the demersal fish community in the southern Bay of Biscay. Fish Res 52:65-77

Webb PW (1989) Station-holding by three species of benthic fishes. J Exp Biol 145:303-320

Wienerroither R (2001) Species composition of mesopelagic fishes in the area of the Canary Islands, Eastern Central Atlantic. MSc thesis, University of Salzburg

Whitehead PJP, Bauchot ML, Hureau JC, Nielsen J, Tortonese E (1986) Fishes of the North-eastern Atlantic and the Mediterranean. Vols. 1-3. UNESCO, Paris

Yoklavich MM, Greene HG, Cailliet GM, Sullivan DE, Lea RN, Love MS (2000) Habitat associations of deep-water rockfishes in a submarine canyon: an example of a natural refuge. Fish Bull 98:625-641

Zaferman ML (1992) On the behaviour of the blunt-snouted grenadier, Coryphaenoides rupestris, based on underwater observations. J Ichthyol 32:150-158

Zaferman ML, Shibanov VN, Kalugin AN, Yarovoj AS (1991) A study of the behaviour and distribution of rock grenadier in the area of the North Atlantic Ridge using the Sever-2 manned submersible. In: Grechina AS (ed) Biological resources of the thalassobathyal world ocean. Sb-Nauchn Tr Vniro 62-69 (in Russian)

Submitted: October 29, 2002; Accepted: April 23, 2003

Proofs received from author(s): July 7, 2003 